\title{
Characteristics Determining the Livelihood Security of the Tribal Farmers
}

\author{
H.R. Ramya ${ }^{1 *}$, P.V. Satya Gopal ${ }^{2}$, S.V. Prasad ${ }^{2}$ and L. Raja ${ }^{1}$ \\ ${ }^{1}$ Division of Dairy Extension, NDRI, Karnal - 132001, India \\ ${ }^{2}$ Department of Agricultural Extension, S.V. Agricultural College, Tirupati, 517502, India \\ *Corresponding author
}

\begin{tabular}{|c|c|}
\hline & A B S T R A C T \\
\hline & \multirow{6}{*}{$\begin{array}{l}\text { The research study was conducted during the year } 2015 \text { to study relationship } \\
\text { between the personal, socio-economic and psychological characteristics and } \\
\text { livelihood security of the tribal farmers in high altitude tribal zone of Karnataka } \\
\text { state. The study revealed that education, land holding, annual income, extension } \\
\text { contact, mass media exposure, social participation, economic orientation, risk } \\
\text { orientation and level of aspiration had shown positively significant relationship } \\
\text { and fatalism had shown negatively significant relationship with livelihood security } \\
\text { of tribal farmers. On the other side age, farming experience, family type and land } \\
\text { holding had shown non-significant relationship with livelihood security of tribal } \\
\text { farmers. Step wise regression analysisrevealed that annual income, mass media } \\
\text { exposure, family size, risk orientation and fatalism were the major variables to } \\
\text { explain the livelihood security of tribal farmers. The combined effect of these five } \\
\text { variables might have contributed for the Livelihood security of tribal farmers. }\end{array}$} \\
\hline & \\
\hline $\begin{array}{l}\text { Livelihood security, } \\
\text { Tribal Farmers, } \\
\text { Relationship, } \\
\text { Characteristics. }\end{array}$ & \\
\hline Article Info & \\
\hline $\begin{array}{l}\text { Accepted: } \\
\text { 30 June } 2017 \\
\text { Available Online: } \\
\text { 10 July } 2017\end{array}$ & \\
\hline & \\
\hline
\end{tabular}

\section{Introduction}

Tribal people are children of nature and their lifestyle is conditioned by the ecosystem. They have followed ways of life for many generations that are largely self-sufficient and are clearly different from the mainstream and dominant society. There are approximately 200 million tribal people in the entire globe accounting for about 4 per cent of the global population.

With more than 84.4 million constituting 8.6 per cent of the total population, India has the largest population of the tribal people in the world and the government has identified more than 697 tribal communities in the country. Tribal communities live in about 15 per cent of the country's area, in various ecological and geo climatic conditions ranging from plains, forests, hills and inaccessible areas.

The tribals have been living in the forest since ancient times; the forest is the backbone of the tribal economy and they are living in remote forest areas. They are facing lots of health problems like malnutrition and diseases, Tribals even today have lack of drinking water, electricity, housing and other basic facilities.

The tribals have to walk long distances for Primary Health Centers for medical treatments. The government has lot of health 
programmes but many services are not reaching the tribal settlements. The problems of the vast tribal population of India are as varied as the tribal groups themselves who present a bewildering diversity and variety in their socio-economic, socio-cultural and ecological settings. The tribal children were consistently more impoverished than their rural counterparts, in part because tribal families typically live in more remote resources poor settings (Sethuraman, 2008). Tribals are beginning to face problems of different intensities because of poverty. This situation has come about because their livelihoods have been compromised by regressive forest protection laws (Pate, 2009). The regular and continuous research in analyzing the relationship between the personal, socio-economic and psychological characteristics and livelihood security of the tribal farmers is having paramount importance to design the strategies for improving the livelihood security of the tribal farmers. Hence the present study was taken up with the objective of analyzing the relationship between the personal, socio-economic and psychological characteristics and livelihood security of the tribal farmersin high altitude tribal zone of Karnataka state.

\section{Materials and Methods}

Ex post facto research design was followed for the study. The Chamaraja Nagara district was purposively selected since it is having highest number of tribal farmers in Karnataka state. All the four ranges viz., Yelandur, Kollegal, Chamaraja Nagara and Punjur of High Altitude Tribal Zone located in Biligiri Rangana hills (B R Hills) of Chamaraja Nagara district were selected for the study. Two villages from each range were selected by following simple random sampling procedure, thus making a total of eight villages for the study. From each of the eight selected villages, 15 respondents were selected by following simple random sampling procedure, thus making a total of 120 respondents. The relationship between the personal, socio-economic and psychological characteristics and livelihood security of the tribal farmers was computed by co-efficient of correlation and multiple linear regression analysis. In the present study the livelihood security of tribal farmers was operationalized as the degree of accessibility, adequacy and utility of different resources to meet the basic needs of the family. An index was constructed to measure livelihood security of tribal farmers based on extensive review of literature and in consultation with the extension experts. The multidimensional aspect of livelihood security comprises twelve components viz., food and nutritional security, habitat security, cultural security, asset security, health security, economic security, financial security, educational security, social security, transportation security, information security and occupation security. The correlation analysis was carried out for the overall livelihood security of tribal farmers as well as for all the twelve components of livelihood security of tribal farmers, This analysis has thrown light on the importance and relationship of each component with the independent variables.

\section{Results and Discussion}

In order to study the nature of relationship, the data related to the above variables were subjected to correlation coefficient analysis and step wise multiple regression analysis. The values of correlation coefficients (r) and step wise multiple regression analysis was then tested for their statistical significance.

Correlation analysis of the personal, socioeconomic and psychological characteristics and livelihood security of the tribal farmers

In order to study the nature of relationship between the selected independent variables 
and livelihood security of the tribal farmers, correlation coefficient (r) was computed and the values are presented in table 1 and figure 1. The values of correlation coefficients (r) were then tested for their statistical significance.

\section{Age Vs livelihood security of tribal farmers}

Age has shown non-significant $(r=0.008 \mathrm{NS})$ relationship with livelihood security of tribal farmers. On the same line, all other components of livelihood securities also had shown non-significant relationship except educational security, food and nutritional security, social security, health security and information which was negatively significant with the age of tribal farmers. Irrespective of age, all the tribal farmers might be under different levels of security due to their other personnel, social psychological and organizational variables. Age might be determining the level of responsibility rather than level of security. Further it can also be interpreted that young age tribals might be possessing enough education qualifications and utilizing the available education facilities than the old age tribal farmers.

\section{Education Vs livelihood security of tribal farmers}

Education was found to have positively significant $(r=0.224 *)$ relationship with overall livelihood security of the tribal farmers. Critical examination of different components of livelihood security shows that asset security, social security, financial security and educational security also shown the same relationship whereas the other securities have shown non-significant relationship. Education is the base for better standard of living. It develops potential for efficient utilization of all available resources towards their growth and development which in turn leads to high livelihood security. The education of tribal farmer might be more logical and optimistic in their way of thinking towards their life style adjustments which will strengthen their livelihood security. Particularly the generation of assets, prominent social interaction, judicious day to day expenditure, possession and availment of educational facilities might be due to their telescopic faculties derived through high level of education of tribal farmers.

\section{Farming experience Vs livelihood security of tribal farmers}

The relationship of farming experience with livelihood security was found to be nonsignificant $(r=0.083 \mathrm{NS})$. On the same line, all the twelve components of livelihood security also have shown the non-significant relationship with farming experience of tribal farmers. It can be interpreted that experience gained through their farming might not be a source of enhancing their livelihood security.

Rather than the farming experience might have just passed their life without much significant changes in their life style. In contrary, the age factor and interest towards education among the young tribals might have produced high educational security than old age tribal farmers and put up less farming experience.

\section{Land holding Vs livelihood security of tribal farmers}

It was found that farm size had shown the positive significant $\left(\mathrm{r}=0.365^{* *}\right)$ relationship with the livelihood security. On the same line all the different components of total livelihood securities have shown positive significant relationship except habitat security, social security and transportation security had shown non-significant relationship. Possession of land is the mark of independence. The tribal farmers might be cultivating different crops in their available land and generating income for their 
livelihood. In the absence of land, they might be in search of forest based activities and other avenues which might not have given enough income to lead their family. Hence high farm size might have shown positive significant relationship with livelihood security.

Further the farm size also contributed equally to all the securities of livelihood by way of giving an opportunity and ability to tribal farmers to utilize the resources. Farm size might have given scope to enrich their diet, health, assets, finance, education, information etc. through the degree of self-sufficiency and self-reliance.

\section{Annual income Vs livelihood security of tribal farmers}

The relationship between annual income and livelihood security was found to be positively significant $\left(\mathrm{r}=0.843^{* *}\right)$ and all the different components which comes under livelihood security were found to be positively correlated with the annual income except occupational security which was found to be non-significant. Income is the ultimate standard to measure the livelihood security.

The generation of income reflects not only relative wealthiness but also involves intellectual potential of the person to generate enough annual income. Hence high level of annual income not only contributes for meeting the day to day requirements but also widens the scope for exploiting the creative ways for generating further more income and also the sense of saving. It also might have motivated the tribal farmers to take care of food and nutrition, habitat, assets, health, education, transportation, information etc. on the other side some tribal farmers with large family in spite of having enough land holding, might be going for migration.

\section{Family type Vs livelihood security of tribal farmers}

Family type has shown negatively nonsignificant $(r=-0.063 \mathrm{NS})$ relationship with the livelihood security of tribal farmers. An analysis of different components of livelihood securities has shown that educational security had shown the positive significant relationship whereas the other securities have shown non-significant relationship with the family type. In both the nuclear and joint families there might be similar scope for utilization of resources in turn led to similar level of livelihood security. The matter of human relations and pattern of dependence might be the significant factors differentiating the nuclear and joint families than the extent of livelihood securities. But the education security is positive due to relatively more independence and responsibility in nuclear families.

\section{Family size Vs livelihood security of tribal farmers}

Family size was non-significantly related with the livelihood security $(r=0.108 \mathrm{NS})$ of tribal farmer. But food and nutritional security, asset security, educational security and information securities had shown positively significant relationship with family size. The possible reason for non-significant relationship might be that, in some cases greater family size might have given more scope for earning their income by involving more number of family members as well as utilizing other resources led to the high livelihood security. On the other side, greater family size with less number of earning people in the family led to low livelihood security. In the nuclear families, the role of their current level of personnel and economic factors might have played a key role in having variation on livelihood security. 


\section{Extension contact Vs livelihood security of} tribal farmers

The relationship between extension contact and livelihood security was found to be positively significant $\left(0.497^{* *}\right)$. Except educational security, all other securities have shown positively significant relationship with extension contact. The contact with various extension agencies will widen the versatility of an individual.

It is a source of updating the knowledge and skills ultimately led to building selfconfidence. Greater the extension contact by the tribal farmers, more will be the scope for developing the potential to make use of their available resources to maximize the output. This also facilitates the tribal farmers to tune their life style towards socio-psychological, organizational and economic maturity.

The similar trend on all the securities also signifies the holistic development of tribals in all the angles through effective extension contact.

\section{Mass media exposure Vs livelihood security of tribal farmers}

Mass media exposure has shown positively significant relationship $\left(0.666^{* *}\right)$ with livelihood security of tribal farmers and in the same line all other components of livelihood security had depicted positive significant relationship. Media utilization is the sign of civilization. Even though mass media are the main sources of creating awareness, they also act as gateways for creativity and innovation.

The tribal farmers who were in touch with different mass media might be updating their current trends through ground breaking approaches which might have refined their life style over a period of time. The accessibility of different mass media among the tribal communities also greatly contributed to the above trend. In the same lines of extension contact, the mass media utilization also might have explored the scope for holistic and integrated development of tribal farmers. Hence it has shown significant relationship with all securities of livelihood.

\section{Social participation Vs livelihood security of tribal farmers}

Social participation had shown a positively significant relationship $\left(0.597^{* *}\right)$ with livelihood security of tribal farmers. In the same line all the other securities also had shown the same positively significant relationship except occupational security. Theory of "Need hierarchy" can be interpreted for this positive significant relationship. As a human being, everybody wants to prioritize their basic needs of food, clothing and shelter followed by their protection. Further they can think for social interaction, prestige and so on. The existence of social participation among the tribal farmers might have come only after satisfying their basic needs and their protection. Hence the tribal farmer with high social participation might have had high livelihood security. Social participation might have also developed leadership qualities among tribal farmers which motivated them towards effective group dynamics among tribals.

\section{Economic orientation Vs livelihood security of tribal farmers}

A positively significant relationship $(\mathrm{r}=$ $\left.0.352^{* *}\right)$ was observed between economic orientation and livelihood security of tribal farmers. Majority of the components of the livelihood security also have shown same trend except health, education and transportation securities. 
Table.1 Relationship between the selected independent variables and livelihood security of the tribal farmers

\begin{tabular}{|c|c|c|c|c|c|c|c|c|c|c|c|c|c|}
\hline $\begin{array}{c}\text { Independent } \\
\text { variables }\end{array}$ & $\begin{array}{c}\text { F \& N } \\
\text { security } \\
(\mathbf{r})\end{array}$ & $\begin{array}{l}\text { Habitat } \\
\text { security } \\
(\mathbf{r})\end{array}$ & $\begin{array}{c}\text { Cultural } \\
\text { security } \\
(r)\end{array}$ & $\begin{array}{c}\text { Asset } \\
\text { security } \\
\text { (r) }\end{array}$ & $\begin{array}{c}\text { Health } \\
\text { security } \\
\text { (r) }\end{array}$ & $\begin{array}{c}\text { Social } \\
\text { security } \\
(\mathbf{r})\end{array}$ & $\begin{array}{c}\text { Economic } \\
\text { security } \\
(r)\end{array}$ & $\begin{array}{c}\text { Financial } \\
\text { security } \\
(r)\end{array}$ & $\begin{array}{c}\text { Educationa } \\
\text { I security } \\
\text { (r) }\end{array}$ & $\begin{array}{c}\text { Transportatio } \\
\text { n security } \\
\text { (r) }\end{array}$ & $\begin{array}{c}\text { Information } \\
\text { security } \\
\text { (r) }\end{array}$ & $\begin{array}{c}\text { Occupationa } \\
\text { I } \\
\text { Security } \\
\text { (r) }\end{array}$ & $\begin{array}{l}\text { Livelihood } \\
\text { security } \\
\text { (r) }\end{array}$ \\
\hline Age & -0.012 & 0.109 & 0.06 & 0.094 & -0.092 & -0.037 & 0.076 & 0.076 & -0.267 & 0.115 & -0.013 & 0.13 & $0.008 \mathrm{NS}$ \\
\hline Education & 0.148 & 0.038 & 0.104 & $0.188^{*}$ & 0.052 & $0.211^{*}$ & 0.171 & $0.231 * *$ & $0.233 * *$ & -0.043 & 0.199 & 0.069 & $0.224 *$ \\
\hline $\begin{array}{c}\text { Farming } \\
\text { experience }\end{array}$ & 0.078 & 0.118 & 0.118 & 0.171 & -0.084 & -0.001 & 0.049 & 0.146 & -0.199 & 0.13 & 0.044 & 0.158 & $0.083 N S$ \\
\hline Land holding & $0.33 * *$ & 0.115 & $0.347 * *$ & $0.391 * *$ & $0.336 * *$ & 0.166 & $0.241 * *$ & $0.291 * *$ & $0.201 *$ & 0.029 & $0.267 * *$ & $0.317 * *$ & $0.365 * *$ \\
\hline $\begin{array}{l}\text { Annual } \\
\text { income }\end{array}$ & $0.807 * *$ & $0.298 * *$ & $0.387 * *$ & $0.563 *$ & $0.256^{* *} *$ & $0.406^{* *}$ & $0.897 * *$ & $0.598 * *$ & $0.265^{* *}$ & $0.334 * *$ & $0.532 * *$ & 0.086 & $0.843 * *$ \\
\hline Family type & 0.043 & -0.059 & -0.008 & 0.026 & 0.007 & -0.078 & -0.182 & -0.092 & $0.221 *$ & 0.068 & -0.018 & -0.009 & $-0.063 N S$ \\
\hline Family size & $0.257 * *$ & 0.119 & 0.172 & $0.282 * *$ & 0.166 & 0.134 & -0.193 & 0.027 & $0.309 * *$ & 0.158 & $0.278 * *$ & 0.096 & $0.108 N S$ \\
\hline $\begin{array}{c}\text { Extension } \\
\text { contact }\end{array}$ & $0.389 * *$ & $0.331 * *$ & $0.423 * *$ & $0.431 * *$ & $0.189 *$ & $0.547 * *$ & $0.278 * *$ & $0.542 * *$ & -0.001 & $0.265^{* *}$ & $0.474 * *$ & $0.27 * *$ & $0.497 * *$ \\
\hline $\begin{array}{c}\text { Mass media } \\
\text { Exposure }\end{array}$ & $0.591 * *$ & $0.454 * *$ & $0.532 * *$ & $0.743 * *$ & $0.280 * *$ & $0.519 * *$ & $0.356^{* *}$ & $0.583 * *$ & $0.204 *$ & $0.452 * *$ & $0.661 * *$ & $0.202 * *$ & $0.666 * *$ \\
\hline $\begin{array}{c}\text { Social } \\
\text { participation }\end{array}$ & $0.529 * *$ & $0.263 * *$ & $0.512 * *$ & $0.584 * *$ & $0.294 * *$ & $0.518 * *$ & $0.398 * *$ & $0.485^{* *}$ & $0.225^{*}$ & $0.302 * *$ & $0.535^{* *}$ & 0.05 & $0.597 * *$ \\
\hline $\begin{array}{c}\text { Economic } \\
\text { orientation }\end{array}$ & $0.257 * *$ & $0.319 * *$ & $0.218 * *$ & $0.227 *$ & 0.09 & $0.422 * *$ & $0.225^{* *}$ & $0.410 * *$ & -0.046 & 0.131 & $0.354 * *$ & $0.219^{*}$ & $0.352 * *$ \\
\hline $\begin{array}{c}\text { Risk } \\
\text { orientation }\end{array}$ & $0.237 * *$ & $0.197 * *$ & $0.183^{*}$ & $0.276^{* *}$ & 0.11 & $0.373 * *$ & $0.221 *$ & $0.335^{* *}$ & -0.003 & 0.088 & $0.328 * *$ & $0.29 *$ & $0.324 * *$ \\
\hline $\begin{array}{c}\text { Level of } \\
\text { aspiration }\end{array}$ & $0.496 * *$ & 0.059 & $0.342 * *$ & $0.377 * *$ & $0.331 * *$ & $0.312 * *$ & $0.257 * *$ & $0.219^{*}$ & $0.493 * *$ & 0.085 & $0.216^{*}$ & -0.209 & $0.383 * *$ \\
\hline Fatalism & $-0.394 *$ & -0.164 & $-0.372 * *$ & $\begin{array}{c}- \\
0.428 * *\end{array}$ & $-0.314 *$ & $\begin{array}{c}- \\
0.352^{*} * \\
\end{array}$ & $-0.407 * *$ & $-0.427 * *$ & -0.119 & $-0.215^{*}$ & $-0.371 * *$ & -0.052 & $-0.491 * *$ \\
\hline
\end{tabular}


Table.2 Step wise regression analysis of the selected independent variables with the Livelihood security of tribal farmers

\begin{tabular}{|l|l|l|l|l|l|}
\hline $\begin{array}{l}\text { S. } \\
\text { No. }\end{array}$ & Vumber & Independent Variables & $\begin{array}{l}\text { Partial } \\
\text { regression } \\
\text { Coefficients }(\mathbf{b})\end{array}$ & $\begin{array}{l}\text { Beta } \\
\text { Weight } \\
\left(\mathbf{b}^{\prime}\right)\end{array}$ & $\begin{array}{l}\text { 't' value on the } \\
\text { partial(b) }\end{array}$ \\
\hline 1 & $\mathrm{X} 5$ & Annual income & 0.000 & 0.643 & $13.841^{* *}$ \\
\hline 2 & $\mathrm{X} 9$ & Mass media exposure & 2.021 & 0.331 & $7.248^{* *}$ \\
\hline 3 & $\mathrm{X} 7$ & Land holding & -1.033 & -0.110 & $-2.691^{* *}$ \\
\hline 4 & $\mathrm{X} 12$ & Risk orientation & 0.643 & 0.106 & $2.671^{* *}$ \\
\hline 5 & $\mathrm{X} 14$ & Fatalism & -1.036 & -0.104 & $-2.396^{*}$ \\
\hline $\mathrm{R}^{2}=0.826$ & $\mathrm{~F}=113.249^{* *}$ & $\mathrm{~d}$ & \\
\hline
\end{tabular}

A tribal farmer with high economic orientation might be seeking towards high returns from his meagre source of income. They always strive hard in getting the required income for their family. In due course of time, they might be thinking about their quality of work and the income generated from it.

High economic orientation might be developing a sense of effective and efficient utilization of earned income towards different components of their livelihood security. Because of their ignorance and some situational factors, there might be discrepancy in relationship on health, education and transport securities with economic orientation.

\section{Risk orientation Vs livelihood security of tribal farmer}

The relationship between risk orientation and livelihood security of tribal farmers was found to be positively significant $(\mathrm{r}=$ $0.324 * *)$. In the same lines of economic orientation relationship health security, education security and transportation security has shown non-significant relationship. The other securities have shown similar trend of positively significant relationship with risk orientation. Risk is a necessary evil for the growth and development. Taking calculated risk is mandatory for the survival and existence. As a tribal farmer, the degree of risk varies from person to person and might be reflecting the differences in their livelihood security. High risk orientation among the tribal farmers might be exploring them to different sources of income and different ways \& means for their growth. Fear of risk among tribals might be in retaining them under more and trivial condition. The tribal farmers might be in the opinion that the health, education and occupational securities were in consequential for taking risk.

\section{Level of aspiration Vs livelihood security of tribal farmers}

Level of aspiration was found to have positively significant $(0.383 * *)$ relationship with livelihood security of tribal farmers. With regard to component of livelihood security, habitat security, transportation security and occupational security securities have shown non- significant relationship and 
other securities have shown significant relationship with level of aspiration. Higher the level of aspiration greater the scope for working towards set goals. A tribal farmer might be targeting their activities in varying degrees based on their level of aspiration. This variation leads to difference in their extent of utilization of resources and reflects their livelihood security. The level of aspiration of tribal farmers might be less focused on habitat and transportation securities.

\section{Fatalism Vs livelihood security of tribal farmers}

Fatalism had shown negatively significant relationship $(-0.491 * *)$ with livelihood security of the tribal farmers. Accordingly all the components of livelihood security also had shown negatively significant relationship except habitat, education and occupational securities which had shown negatively nonsignificant relationship. Fatalism is the major threat for initiative and creative thinking. But these two elements are mandatory for the growth and development of any endeavour. Being the tribal farmer they might be always in defensive side, due to their established patterns of culture as well as behaviour. They always want to remain in their current life style. They might be in the opinion that traditional ways of doing are apt for their life style and assume that it is the grace of the god. This condition might have back stepped the tribal farmers with high fatalism and not interested to bring some changes in their life style which lead to low livelihood security. On the other side, some of the tribal farmers with their education, contact with extension agencies and other factors might have reduced the fatalism and took initiative towards their development.

The overall correlation analysis between personal, socio-economic and psychological characteristics of tribal farmers and their livelihood security revealed that education, land holding, annual income, extension contact, mass media exposure, social participation, economic orientation, risk orientation and level of aspiration had shown positively significant relationship and fatalism had shown negatively significant relationship with livelihood security of tribal farmers. Hence the null hypothesis was rejected and empirical hypothesis was accepted for the above variables. On the other side age, farming experience, family type and land holding had shown non-significant relationship with livelihood security of tribal farmers. Hence null hypothesis was accepted and empirical hypothesis was rejected for the above variables. The findings of the present study were similar to that ofMahadik and Sawant (2012) and Dhanashree (2013).

\section{Pooled effect of all the selected independent variables on livelihood security of the tribal farmers}

In explaining the variation in effect of all selected independent variables on livelihood security of tribal farmers, multiple linear regression (MLR) analysis was carried out to find the relationship of livelihood security with all other variables and to identify the important explanatory factors of livelihood security. Regression was run on SPSS 20.0.and the following model was arrived with the stepwise regression equation.

Livelihood security $\left(Y_{1}\right)=37.474+0.000 X_{5}$ $+2.021 X_{9}-1.033 X_{7}+0.643 X_{12}-1.036 X_{14}$

Where,

$\mathrm{Y}_{1}=$ Livelihood security

$\mathrm{X}_{5}=$ Annual income

$\mathrm{X}_{9}=$ Mass media exposure

$\mathrm{X}_{7=}$ Land holding

$\mathrm{X}_{12}=$ Risk orientation

$\mathrm{X}_{14}=$ Fatalism 
It is evident from the table 2. That the variables age, education, farming experience, land holding, family type, extension contact, social participation, economic orientation and level of aspiration were not selected into the model since their contribution was insignificant. The model has $\mathrm{R}^{2}=0.826$ which means 82.60 per cent of Livelihood security is explained by the model.

The model is also significant by F-test with $\mathrm{F}=113.249$ (significant at $1 \%$ level) $\mathrm{F}$ critical at (118) d.f. All the five regression coefficients were found to be significant. This model can be used to estimate the Livelihood security of a tribal farmer for whom the five variables are specified.

Annual income, mass media exposure, family size, risk orientation and fatalism were the major variables to explain the Livelihood security of tribal farmers. The combined effect of these five variables might have contributed for the Livelihood security of tribal farmers.Mahadik and Sawant (2012) and Dhanashree (2013) reported the similar results.

\section{References}

Dhanasree, K., Vijayabhinandana, B and Pradeepkumar, P.B. 2013. Socioeconomic empowerment of tribal women in high altitude and tribal zone of Andhra Pradesh.International Journal of Innovative Research in Science, Engineering and Technology. 3 (2): 9360-9368.

Mahadik, R.P and Sawant, P. A. 2012. Livelihood security of tribal people in Thane district of Maharashtra.Rajasthan Journal of Extension Education.20: 3943.

Pate, B. 2009, Face to face, splash, published by SVARAJ, Bangalore.

Sethuraman, K. (2008). The role of women's empowerment and domestic violence in child growth and undernutrition in a tribal and rural community in South India: United Nations University, NUWIDER, World Institute for Development Economics Research, Research Paper, No, 2008/15, Helsinki, Finland.

\section{How to cite this article:}

Ramya, H.R., P.V. Satya Gopal, S.V. Prasad and Raja, L. 2017. Characteristics Determining the Livelihood Security of the Tribal Farmers. Int.J.Curr.Microbiol.App.Sci. 6(7): 4462-4470. doi: https://doi.org/10.20546/ijcmas.2017.607.465 